\title{
Irradiation Studies of LED Light Spectra on the Growth and Development of Potato (Solanum tuberosum L.)
}

\author{
Robin Kumar Pundir ${ }^{1}$, Abhishek Pathak ${ }^{1}$, Neha Joshi ${ }^{1}$, Deepak Singh Bagri ${ }^{1,2}$, \& Chandrama Prakash \\ Upadhyaya $^{1^{*}}$ \\ ${ }^{1}$ Potato Phenomics Laboratory, Department of Biotechnology, Dr Harisingh Gour Central University, Sagar 470 003, Madhya Pradesh, India \\ ${ }^{2}$ Department of Botany, Government Degree College, Amanganj, Panna, Madhya Pradesh, India \\ *Email: cpupadhyay1@gmail.com
}

\section{ARTICLE HISTORY}

Received: 15 April 2020

Accepted: 07 June 2020

Published: 12 July 2020

\section{KEYWORDS}

Tuberization; Solanum tuberosum L.; Plant health index; Stomata, Chlorophylls; Soluble proteins; Free radical scavenging enzymes

\begin{abstract}
The study aimed to explore the impacts of distinctive qualities of the LED light (such as to low power consumption, lesser production costs, longer operational lifetime and cool light emission with specific monochromatic wavelength) on potato (Solanum tuberosum L.) growth and development including plant height, number of leaves, root length, fresh and dry weight etc. The accumulation of phytopigments, soluble proteins and sugars, free radical scavenging activity and overall tuber yield were also evaluated. Enhanced plant height with increased diameter and branching was observed with the plant growing under the $B_{100}$ and $R_{30} B_{70}$ LED light combination. Similarly, total number of leaves, leaf surface area, health index, phyto-pigments and tuber yield of potato was also significantly increased as compared to the plant growing under the $\mathrm{W}_{100}$ as control. Soluble proteins and sugar content and free radical scavenging enzyme activity were also significantly enhanced in the $R_{30} B_{70}$ LED light combination. Tubers yield per plants were also enhanced under the RB combination of the LED light. The current study indicated that the combination of $R$ and $B$ LED lights proved better for plant growth and development in a controlled environment and the $R_{30} B_{70}$ is the best combinational spectra for increased growth and tuber yield of potato plants. Therefore, the precise management of the irradiance and wavelength may hold promise in maximizing the economic efficiency of potato production, and quality of this important vegetables grown in controlled environments.
\end{abstract}

\section{Introduction}

The Potato (Solanum tuberosum L.) is a significant crop worldwide with higher nutritional as well as economic value. It is cultivated throughout the world with a production of 400 million tons every year (1-4). Irradiation of the light is an essential environmental factors affecting plant development (5). Plants respond to different factors of light including the quality (wavelength), quantity (intensity) and duration (6). Light has a remarkable effect on the seed propagation, leaf magnitude, leaf structure, plant stature, flowering and fruiting as well as the primary and secondary metabolites constituents of the plant (7-10).

The daily light integral (DLI) is a function of photosynthetic light intensity and duration which is usually expressed as moles of light (mol) per square meter $\left(\mathrm{m}^{-2}\right)$ per day $\left(\mathrm{d}^{-1}\right)$. An increase in total DLI via supplementary light promotes the growth of greenhouse-grown seedlings. High-pressure sodium (HPS) lamps have been used commonly for the maintenance of plants growing under the greenhouse conditions. The HPS lamp provides the light by emitting the spectral range of 565 to $700 \mathrm{~nm}$ which is important for photosynthesis and overall development including crop productivity. The galliumaluminum-arsenide light-emitting diodes (LEDs) lighting system is modern lighting system has replaced the HPS lamp due to low power consumption, lesser production costs and longer operational lifetime, cool light emission at a specific monochromatic wavelength with user-friendly light intensity/quality that corresponds to the plant photomorphogenesis (1113). Blue spectra of light were reported to promote the development of plant photosynthetic pigments,

(c) Pundir et al (2020). This is an open-access article distributed under the terms of the Creative Commons Attribution License, which permits unrestricted use, distribution, and reproduction in any medium, provided the original author and source are credited (https://creativecommons.org/licenses/by/4.0/).

To cite this article: Pundir R K, Pathak A, Joshi N, Bagri D S, Upadhyaya C P. Irradiation Studies of LED Light Spectra on the Growth and Development of Potato (Solanum tuberosum L.). Plant Science Today. 2020;7(3):406-416. https://doi.org/10.14719/pst.2020.7.3.797 
enhanced photosynthetic product and accumulation of the starch in storage organs (14). The potato plantlets growing under the exposure of red and blue light irradiating from common fluorescent lamps (using appropriate filters) which supported the plant growth and development under in vitro conditions (15). However, the reports on the axillary bud proliferation by red-light or far-red light in potato growing under the in vitro conditions as well as the increase of the leaf chlorophyll content of potato by red fluorescent light and blue light LEDs also confirm the influence of the varied light spectrum on the plant growth $(16,17)$. The blue spectrum of LED light also supported potato growth and development under the in vitro conditions via enhanced number of leaves, stomatal density and enhanced photosynthetic assimilate and biomass (18).

The absorption peak of photosynthetic pigments in plants falls between $440 \mathrm{~nm}$ (blue) and $660 \mathrm{~nm}$ (red) wavelength of light and therefore, the red, as well as blue light or their grouping, may offer proficient light spectrum for better growth and development $(19,20)$. Interestingly, the red and blue light combination was also found to enhance the photosynthesis at the seedling stage and overall plant growth and development (21-23). The plant generally harvests the visible electromagnetic spectrum coming from the sun. However, the visible range of light with a wavelength of 400 to $700 \mathrm{~nm}$ is effective for the carbohydrate synthesis through the photosynthetic reactions $(22,23)$. Effects of various LEDs spectrum have been studied in some agricultural and horticultural crops including the potato (Solanum tuberosum L. (15, 24)), lilium (Lilium lancifolium (22)), Cymbidium lancifolium (12), lettuce (Lactuca sativa (11, 25, 26)), Eucalyptus globulus (27)), Salvia officinalis bedding plants (28), wheat (Triticum aestivum (29)) and spinach (Spinacia oleracea (12, 5, 26)). Maximum studies focused on the function of blue light spectrum on chloroplast development, chlorophyll formation and stomata functioning. Though, the crop responses, in general, have not been broadly exploited, however, it was concluded that the red and blue monochromatic LED light or their combination were suitable for the overall plant growth and development at a definite ratio to meet the requirement of the light spectra effective for photosynthesis. Though each wavelength present in the visible range plays an important role in the synthesis of photosynthetic assimilates and plant development, the red and blue light influences most of the developmental pathways and also involved in tuber formation (tuberization) in case of potato. Therefore, the purpose of the current study was to investigate the influence of monochromatic red, blue LED light and their combination on potato growth and development and to select a suitable-LED light for commercial use of potato cultivation with minimum input. This study also discussed the influences of LEDs as red, blue, with its varied combinations on the growth, tuber yield, primary and secondary metabolites as well as free radical scavenging enzyme activity of potato and mechanism behind these morphological and biochemical changes.

\section{Material and Methods}

\section{Plant material}

Potato cultivar Kufri jyoti, released from the Central Potato Research Institute (CPRI, Meerut station India) which is widely grown in India, was taken for this study. The characteristics of the cultivar include early time to maturity (90-100 days), medium-size tubers and upright plant type. The potato tubers collected were washed in running water to remove soil attached with it and kept for sprouting under the dark humid chamber at $37^{\circ} \mathrm{C}$ for a week. The experiments were done at Potato Phenomics laboratory established at Department of Biotechnology, Dr Harisingh Gour Vishwavidyalaya (A Central University), Sagar, Madhya Pradesh, India $\left(23.8388^{\circ} \mathrm{N}, 78.7378^{\circ} \mathrm{E}\right)$. The plantlets sprouted were then transferred to the pots $(25 \mathrm{~cm})$ filled with agro peat mixed with coco-peat and sand (3:1 ratio) and maintained in the plant growth chambers (Matrix Eco India, size $1.5 \mathrm{~m} \times 1.2 \mathrm{~m} \mathrm{x} 2 \mathrm{~m}$, providing a total growth area of $4.2 \mathrm{~m}^{2}$ with $40-\mathrm{cm}$ high clearance) under control temperature $\left(22.2^{\circ} \mathrm{C} \pm 0.8^{\circ} \mathrm{C}\right)$, and humid conditions $(65 \% \pm 7 \%)$. The experiments were conducted in between year 2016-2019 preferably in the months of October to February which is naturally favourable for the cultivation. The plants were fortified with $50 \mathrm{ml}$ of Hoagland nutrient solution (diluted to 1/10) once a week otherwise plants were watered with tap water as per requirements that is standardized in the laboratory for better plant growth.

\section{The light source and culture conditions}

In this study, the LED light source was procured from the supplier (Jay Appliances Sagar, Madhya Pradesh, make Syska, India) with the corresponding $\mathrm{R}$ (650 $\mathrm{nm}$ ) and B (460 nm) wavelength. The LED source comprised of longer stripe $(5 \times 100 \mathrm{~cm})$ containing 40 LEDs, which created a light-emitting set with 100 $\mu \mathrm{mol} \mathrm{m}-^{2} \mathrm{~s}-{ }^{1}$ total photosynthetic photon flux density (PPFD). The plants were subjected to the monochromatic Red (R) and Blue (B) LED such as $100 \% \mathrm{R}\left(\mathrm{R}_{100}\right), 100 \% \mathrm{~B}\left(\mathrm{~B}_{100}\right)$, and various combinations of $\mathrm{RB}$ such as $30 \% \mathrm{R}-70 \% \mathrm{~B}\left(\mathrm{R}_{30} \mathrm{~B}_{70}\right), 50 \% \mathrm{R}-50 \% \mathrm{~B}$ $\left(\mathrm{R}_{50} \mathrm{~B}_{50}\right), 70 \% \mathrm{R}-30 \% \mathrm{~B}\left(\mathrm{R}_{70} \mathrm{~B}_{30}\right)$ LED spectra. The $\mathrm{W}_{100}$ LED without supplementation of $R$ and $B$ LED used as a control. Wavelengths of $\mathrm{R}$ and $\mathrm{B}$ LED were procured from the company mentioned at $660 \mathrm{~nm}$ and $440 \mathrm{~nm}$ respectively. The photo period, photosynthetic photon flux density (PPFD), day/night temperature and relative humidity were 16/8 $\mathrm{h}$ (day/night), 210 umol m $\mathrm{m}^{-2} \mathrm{~s}^{-1}, 22 \pm 2{ }^{0} \mathrm{C}, 65 \pm 5 \%$ in the plant growth chambers respectively following protocol (47) with slight modification suitable for the experiments.

\section{Evaluation of plant growth traits}

The plant height $(\mathrm{cm})$, stem diameter (in $\mathrm{mm}$, and measured $5 \mathrm{~cm}$ above the ground), number of branches, number of leaves, leaf area, plant fresh and dry weight were quantified upon 15-day interval till the harvesting of potato. The plant health index, total phyto-pigments, starch, soluble proteins, soluble sugar, total phenolics, ROS scavenging enzyme and ascorbate contents were quantified as per standard protocols $(17,50)$. The health index was determined 
using the equation: Health index = Stem diameter/Stem height $\mathrm{x}$ Dry mass. For each trait, 3 replicates with 5 plants were taken to the experiments. The tubers yield per plants (g), tuber size (mm) and tuber fresh/dry weight (g) were also analyzed upon the full maturity by harvesting potato tubers.

\section{Study of leaf stomata}

Fresh tender leaves collected from the plants growing under the LED light and translucent nail polish was applied to it a little apart from the main vein as and kept for drying as standardized in laboratory following the published protocol (30). A clear adhesive tape was pasted onto the leaf which was then softly peeled-off from the leaf which contains the leaf epidermal part. This was observed under a confocal microscope [Nikon LSCM (NIS-Elements AR 4.20.00 64-bit)] and quantification of stomata was done as per the standard procedure (30).

\section{Extraction and estimation of phyto-pigments}

Estimation of the chlorophyll content was done following the standard protocol (31) in the leaves of potato grown under the different LED treatments. The leaves $(100 \mathrm{mg}$ ) were homogenized in $10 \mathrm{ml}$ of ice-cold acetone (80\%). The homogenate was centrifuged at $5000 \mathrm{~g}$ for $10 \mathrm{~min}$ (Hermle, Germany, Model Z326K) and the supernatant collected was used for estimation of $\mathrm{Chl} \mathrm{a,} \mathrm{Chl} \mathrm{b,} \mathrm{Chl} \mathrm{a/b} \mathrm{ratio,} \mathrm{total} \mathrm{Chl}$ and total carotenoids. Absorbance was recorded at 663, 645, 650, 510 and $470 \mathrm{~nm}$ in Spectrophotometer (Shimadzu, UV-160). Reference cuvette contained $80 \%$ acetone. Chlorophyll assay and carotenoids were estimated as reported earlier $(32,33)$.

\section{Estimation of total carbohydrates, and soluble proteins}

The soluble sugar was extracted as reported earlier and quantified using the phenol sulfuric acid method $(34,35)$. Concentrated sulfuric acid causes hydrolysis of glycosidic linkages; these hydrolyzed neutral sugars were then partially dehydrated with the elimination of three molecules of water to form furfural or furfural derivatives. The colored compounds developed by the condensation of furfural or furfural derivatives with phenol were measured at $490 \mathrm{~nm}$. Starch from fresh leaf and tuber samples was estimated by the anthrone method (36). Soluble proteins were extracted using phosphate buffer and quantified using Coomassie-Brilliant Blue G-250 (37).

\section{Estimation of total phenolics content}

Total phenolics were extracted from leaves of potato using ethanol (80\%) and estimated following the Folin-Ciocalteau reagent (38). The total polyphenols were estimated by spectrophotometer (Shimadzu 1800, Japan) at $660 \mathrm{~nm}$ and calculated in comparison with a standard curve of gallic acid. Results were expressed as gallic acid per g FW.

\section{Quantification of ROS scavenging enzyme activity}

The crude proteins isolated from the leaves were used for the enzyme estimation. The SOD activity was evaluated by standard protocol (39). One unit of SOD was defined as the enzyme activity that inhibited the photo-reduction of nitroblue tetrazolium (NBT) to blue formazan by $50 \%$, and SOD activity of the extracts was expressed as NBT units mg protein ${ }^{-1}$ $\min ^{-1}$. Estimation of the CAT activity was done following the standard protocol using spectrophotometric method via a decrease in absorbance of $\mathrm{H}_{2} \mathrm{O}_{2}$ at $240 \mathrm{~nm}$ which expressed as nmol of $\mathrm{H}_{2} \mathrm{O}_{2}$ decomposed $\mathrm{mg}$ protein ${ }^{-1}$ min $-^{1}$ (40). The APX was assayed by the method as published and expressed as $\mathrm{m}$ mol of guaiacol oxidized mg protein ${ }^{-1}$ $\min ^{-1}(41)$. One unit of APX activity was defined as an absorbance change of 0.01 units $\mathrm{min}^{-1}$. The spectrophotometric assay of ascorbate content was done following the protocol reported earlier (42), which was based on the oxidation ascorbic acid to dehydroascorbic acid by bromine water in the presence of acetic acid. A coupling reaction with buffer containing the metaphosphoric - acetic acid solution and 2, 4-dinitrophenylhydrazine (DNPH) results in the development of a red complex and absorbance of the complex was measured at $521 \mathrm{~nm}$ at a spectrophotometer (Shimadzu1800, Japan).

\section{Statistical analysis}

The data were reported as the mean of three replicates $( \pm$ standard deviations, SD). Data were analyzed by variance and Tukey's test (71) with the statistical package SPSS 15.0, unless otherwise stated.

\section{Results}

\section{Effect on plant growth parameters grown under} various LEDs light spectrum

The growth parameters such as the plant height, stem diameter number of leaves etc were significantly changed exposed to various LED light spectrum (Fig. 1). The plants exposed to the monochromatic $R_{100} L E D$ light spectra exhibited an elongation in plant height parameter $(39.25 \pm 3.52 \mathrm{~cm})$ with thinner stem diameter $(0.57 \pm 0.13 \mathrm{~mm})$, and lesser number of leaves $(52 \pm 7.1)$ while the plants exposed to $B_{100}$ LED spectra stunted morphology $(22.11 \pm 3 \mathrm{~cm})$ with thicker stem diameter $(1.59 \pm 0.2 \mathrm{~mm})$ and improved branching (Table 1). Interestingly, the plants exposed to $R_{30} B_{70}$ combination spectra displayed elongated plant height $(28.25 \pm 3 \mathrm{~cm})$, improved stem diameter $(0.543 \pm 0.17$ $\mathrm{mm}$ ) with multiple branches (up to $13.6 \pm 1$ in number), enhanced plant fresh weight (24.5 \pm 8$)$, dry

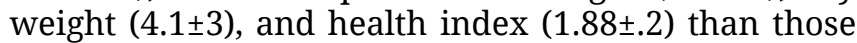
of plants exposed to the $W_{100}$ LED light. Other growth parameters such as number of leaves, and leaf surface area were also enhanced with the plants exposed to the $\mathrm{R}_{30} \mathrm{~B}_{70}$ combination of LED spectra in comparison to the control $W_{100}$ LED light (Table 1).

\section{Stomatal analysis}

The stomatal density (number of stomata per $\mathrm{mm}^{2}$ ) in the plant leaves exposed to the $B_{100}$ and $R_{30} B_{70}$ LED combination light spectra were improved up to 2.2 and 1.48 times in comparison to the plants exposed to the monochromatic $\mathrm{R}_{100}$ and $\mathrm{W}_{100}$ LED spectra respectively. Moreover, the stomatal index (\%) also significantly enhanced with the plants exposed to the $\mathrm{R}_{30} \mathrm{~B}_{70}$ combination of LED spectra (Table 2). 


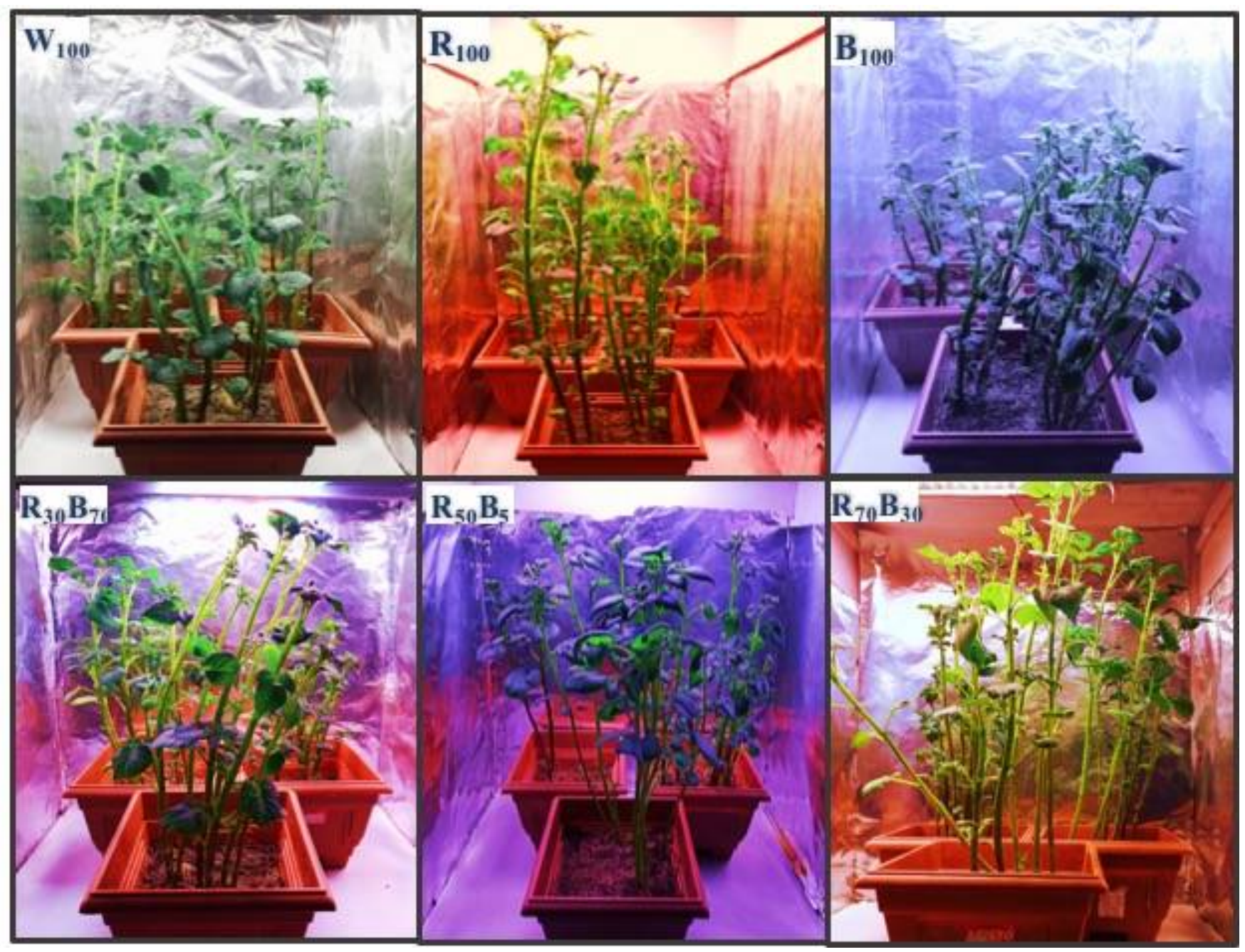

Fig.1. A representative photograph of the potato plants taken upon 4 weeks growing under different LED spectra.

The growth parameters of potato plants were prominently influenced by various LED light spectrum growing in the plant growth chamber. $\mathrm{W}_{100}$ denotes $100 \%$ white LED light ; $\mathrm{R}_{100}, 100 \%$ Red light; $\mathrm{B}_{100}, 100 \%$ Blue light; $\mathrm{R}_{30} \mathrm{~B}_{70}, 30 \%$ Red and $70 \%$ Blue; $\mathrm{R}_{50} \mathrm{~B}_{50}, 50 \%$ Red and $50 \%$ Blue; $\mathrm{R}_{70} \mathrm{~B}_{30}, 70 \%$ Red and $30 \%$ Blue.

Table 1. Morphological parameters of potato plantlets growing under various LEDs light spectrum

\begin{tabular}{|c|c|c|c|c|c|c|}
\hline & LED W $_{100}$ & LED $R_{100}$ & LED B $B_{100}$ & LED $\mathbf{R}_{50} \mathbf{B}_{50}$ & LED $\mathbf{R}_{30} \mathbf{B}_{70}$ & $\mathbf{R}_{70} \mathbf{B}_{30}$ \\
\hline Plant height (cm) & $36.37 \pm 2.41^{\mathrm{a}}$ & $39.25 \pm 3.52^{\mathrm{a}}$ & $22.11 \pm 3.00^{\mathrm{a}}$ & $31.75 \pm 2.09^{\mathrm{a}}$ & $28.25 \pm 3.11^{\mathrm{b}}$ & $33.25 \pm 2.51^{\mathrm{a}}$ \\
\hline Stem diameter $(\mathrm{mm})$ & $1.05 \pm 0.14^{\mathrm{a}}$ & $0.57 \pm 0.13^{\mathrm{a}}$ & $1.59 \pm 0.24^{\mathrm{a}}$ & $0.78 \pm 0.28^{\mathrm{a}}$ & $1.22 \pm 0.17^{\mathrm{ba}}$ & $0.543 \pm 0.17^{\mathrm{b}}$ \\
\hline No. of branches & $08.94 \pm 1.69^{\mathrm{ab}}$ & $09 \pm 1.74^{\mathrm{a}}$ & $12.05 \pm 0.82^{\mathrm{b}}$ & $10.5 \pm 1.50^{\mathrm{a}}$ & $13.61 \pm 1.70^{\mathrm{ab}}$ & $10.5 \pm 1.98^{b}$ \\
\hline No. of leaves & $67.69 \pm 10.25^{b}$ & $52 \pm 7.196^{\mathrm{ab}}$ & $72.22 \pm 6.28^{\mathrm{ab}}$ & $62.58 \pm 4.19^{\mathrm{ab}}$ & $76.33 \pm 11.81^{\mathrm{b}}$ & $52.67 \pm 7.85^{\mathrm{ab}}$ \\
\hline Leaf area $\left(\mathrm{mm}^{2}\right)$ & $12.15 \pm 2.15^{\mathrm{a}}$ & $08.88 \pm 1.72^{\text {ab }}$ & $15.53 \pm 2.73^{b}$ & $12.06 \pm 1.88^{\mathrm{a}}$ & $20.65 \pm 2.24^{\mathrm{a}}$ & $12.23 \pm 1.19^{\mathrm{ab}}$ \\
\hline Plantlet fresh weight (g) & $17.4 \pm 7.26^{\mathrm{a}}$ & $11.88 \pm 6.10^{\mathrm{b}}$ & $24 \pm 7.11^{\mathrm{ab}}$ & $17 \pm 75.25^{\mathrm{b}}$ & $24.5 \pm 8.26^{\mathrm{a}}$ & $18.6 \pm 7.24^{\mathrm{b}}$ \\
\hline Plantlet dry weight (g) & $2.3 \pm 2.20^{\mathrm{ab}}$ & $1.78 \pm 3.10^{\mathrm{bc}}$ & $3.5 \pm 3.11^{\mathrm{b}}$ & $2.2 \pm 2.14^{\mathrm{bb}}$ & $4.1 \pm 3.22^{\mathrm{a}}$ & $2.4 \pm 2.20^{a}$ \\
\hline Health index & $0.75 \pm 0.05^{\mathrm{ab}}$ & $0.48 \pm 0.15^{\mathrm{ab}}$ & $1.58 \pm 0.20^{\mathrm{ab}}$ & $0.65 \pm 0.12^{\mathrm{ab}}$ & $1.88 \pm 0.23^{\mathrm{a}}$ & $0.65 \pm 0.05^{\mathrm{ab}}$ \\
\hline
\end{tabular}

Means followed by a different letter within a row are significantly different at $\mathrm{P}<0.05$ according to the according to Tukey's test.

W, $100 \%$ White; $\mathrm{R}_{100}, 100 \%$ Red; $\mathrm{B}_{100}, 100 \%$ Blue; $\mathrm{R}_{30} \mathrm{~B}_{70}, 30 \%$ Red and $70 \%$ Blue; $\mathrm{R}_{50} \mathrm{~B}_{50}, 50 \%$ Red and $50 \%$ Blue; $\mathrm{R}_{70} \mathrm{~B}_{30}$, $70 \%$ Red and $30 \%$ Blue Means followed by a different letter within a row are significantly different at $\mathrm{P}<0.05$ according to the Duncan’s multiple range test.

Anatomical analysis of stomata revealed an elliptical stomata with the plant leaves growing under eventually all the LED light spectrum, however, a nearly spherical in shape stomata observed with the plant growing under the white LED $\left(\mathrm{W}_{100}\right)$. A comparatively small sized with narrower pore stomata observed with the plants exposed to $R_{100}$ monochromatic LED light, while, enlarged with wider pore stomata were observed with the plant exposed to $\mathrm{R}_{30} \mathrm{~B}_{70} \mathrm{LED}$ combination spectrum (Fig. 2). 


\section{Biochemical Analysis of potato grown under LEDs light spectrum}

A remarkable variation in different biochemical traits of the plants were observed with the plants
Besides, an increase in the ratio of chlorophyll $a / b$ were also observed with the plants exposed to the $\mathrm{R}_{30} \mathrm{~B}_{70}$ combination of LED light spectra (Table 3). A substantial increase in the carotenoids content were also observed with the plant growing under the $\mathrm{R}_{30} \mathrm{~B}_{70}$

Table 2. Effects of LED light spectrum on the size, shape and density of stomata in potato

\begin{tabular}{lcccrrr}
\hline Light Treatment & \multicolumn{1}{l}{ White } & \multicolumn{1}{c}{$\mathbf{R}_{\mathbf{1 0 0}}$} & \multicolumn{1}{c}{$\mathbf{B}_{\mathbf{1 0 0}}$} & \multicolumn{1}{c}{$\mathbf{R}_{\mathbf{5 0}} \mathbf{B}_{\mathbf{5 0}}$} & \multicolumn{1}{c}{$\mathbf{R}_{\mathbf{3 0}} \mathbf{B}_{\mathbf{7 0}}$} & $\mathbf{R}_{\mathbf{7 0}} \mathbf{B}_{\mathbf{3 0}}$ \\
\hline Length $(\boldsymbol{\mu m})$ & $21.29 \pm 0.55 \mathrm{a}$ & $23.16 \pm 0.87 \mathrm{a}$ & $25.08 \pm 0.74 \mathrm{ab}$ & $25.28 \pm 0.47 \mathrm{a}$ & $25.97 \pm 0.53 \mathrm{ab}$ & $23.95 \pm 0.53 \mathrm{a}$ \\
\hline Width $(\boldsymbol{\mu m})$ & $17.86 \pm 0.45 \mathrm{a}$ & $17.55 \pm 0.55 \mathrm{a}$ & $17.79 \pm 0.55 \mathrm{ab}$ & $17.93 \pm 0.44 \mathrm{a}$ & $18.02 \pm 0.45 \mathrm{a}$ & $17.18 \pm 0.35 \mathrm{a}$ \\
\hline Length/Width & $1.17 \pm 0.02 \mathrm{~b}$ & $1.37 \pm 0.02 \mathrm{ab}$ & $1.42 \pm 0.02 \mathrm{~b}$ & $1.41 \pm 0.02 \mathrm{a}$ & $1.44 \pm 0.04 \mathrm{a}$ & $1.39 \pm 0.02 \mathrm{ab}$ \\
\hline $\begin{array}{l}\text { Stomata density } \\
\text { (number per } \mathbf{~ m m}^{2}\end{array}$ & $168.91 \pm 9.06 \mathrm{ab}$ & $129.05 \pm 6.12 \mathrm{a}$ & $195.78 \pm 21.80 \mathrm{~b}$ & $184.23 \pm 11.85 \mathrm{ab}$ & $249.96 \pm 17.50 \mathrm{~b}$ & $189.58 \pm 21.05 \mathrm{~b}$ \\
\hline Stomatal Index \% & $23.53 \pm 4.19 \mathrm{~b}$ & $20.88 \pm 0.68 \mathrm{a}$ & $25.79 \pm 1.98 \mathrm{a}$ & $20.85 \pm 2.06 \mathrm{~b}$ & $26.40 \pm 0.87 \mathrm{~b}$ & $19.75 \pm 0.21 \mathrm{a}$ \\
\hline
\end{tabular}

The RB combination $\left(\mathrm{R}_{30} \mathrm{~B}_{70}\right)$ improve size, shape and activity of the stomata. Stomata density and index were also higher in $\mathrm{B}_{100}$ and $\mathrm{RB}$ combination $\left(\mathrm{R}_{30} \mathrm{~B}_{70}\right)$ LED light in comparison with other LED light treatments.

Mean values followed by a different letter within a row indicate significant differences $(P<0.05)$ according to Tukey's test. Values are mean \pm SE of 5 replications of each set.

W, 100\% White; $\mathrm{R}_{100}, 100 \%$ Red; $\mathrm{B}_{100}, 100 \%$ Blue; $\mathrm{R}_{30} \mathrm{~B}_{70}, 30 \%$ Red and 70\% Blue; $\mathrm{R}_{50} \mathrm{~B}_{50}, 50 \%$ Red and 50\% Blue; $\mathrm{R}_{70} \mathrm{~B}_{30}$, 70\% Red and 30\% Blue.
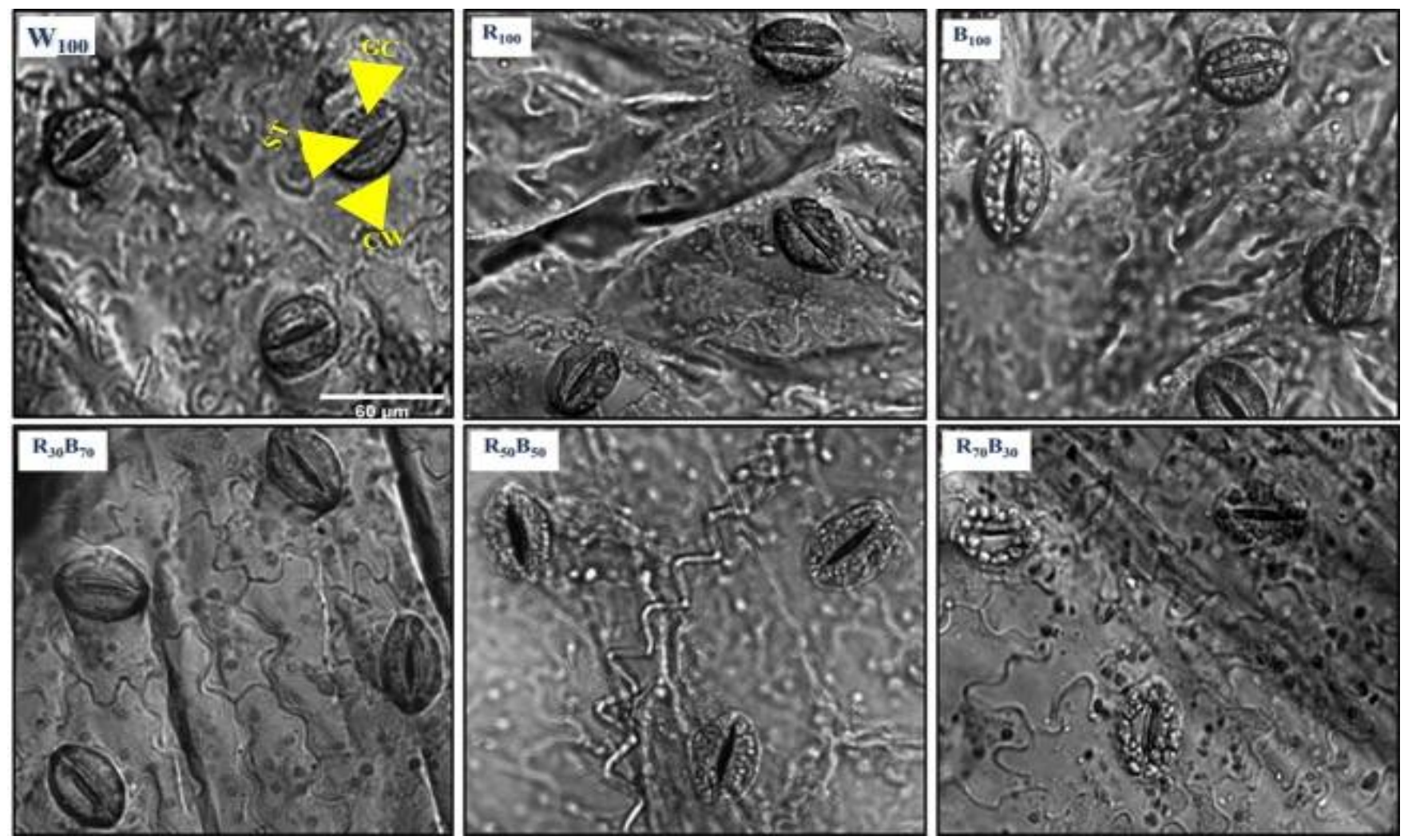

Fig.2. Effect of LED light spectra on leaf stomata of potato plants.

An elliptical-shaped stomata were observed with the plant leaves growing under all the LED spectra except $\mathrm{W}_{100}$ LED light. Stomata with small and narrow pore were observed with the plant growing under the $\mathrm{R}_{100} \mathrm{LED}$, while slightly bigger with a wider pore stomata were observed with those exposed to $\mathrm{R}_{30} \mathrm{~B}_{70}$ LED combination.

Bar - $60 \mu \mathrm{m}$. ST, stomata; CW, cell wall; GC, guard cell.

growing under the monochromatic or the combined LED light spectrum. The biochemical analysis revealed a significant increase in the total chlorophyll $(\mathrm{Chl} \mathrm{a}+\mathrm{b})$ pigments with the plant growing under the monochromatic $\mathrm{B}_{100}$ and the combined LED spectra. The $\mathrm{R}_{30} \mathrm{~B}_{70}$ combination of LED light spectra caused 2 to 2.2 times more chlorophyll content in comparison with the plants growing under the $\mathrm{R}_{100}$ or $\mathrm{W}_{100}$ LED light spectra respectively. combination in comparison with $\mathrm{W}_{100}$ LED light, however, the carotenoids content was found to be minimum $\left(0.16 \pm 0.02 \mathrm{mg} \mathrm{g}^{-1}\right.$ of FW $)$ in the plant exposed to the monochromatic $\mathrm{R}_{100}$ LED light spectra.

Accumulation of carbohydrates (soluble sugars and starch) in the leaves and tubers were significantly improved with the plants exposed to the monochromatic $\mathrm{R}_{100}$ LED spectrum $\left(160 \mathrm{mg} \mathrm{g}^{-1} \mathrm{FW}\right)$ 
Table 3. Effects of LEDs light spectrum on phyto-pigment content in potato

\begin{tabular}{llccccc}
\hline Light Treatment & White & $\mathbf{R}_{\mathbf{1 0 0}}$ & $\mathbf{B}_{100}$ & $\mathbf{R}_{\mathbf{5 0}} \mathbf{B}_{50}$ & $\mathbf{R}_{\mathbf{3 0}} \mathbf{B}_{70}$ & $\mathbf{R}_{70} \mathbf{B}_{\mathbf{3 0}}$ \\
\hline $\begin{array}{l}\text { Chlorophyll- } \mathbf{a} \\
\text { (mg/g of FW) }\end{array}$ & $0.64 \pm 0.07 \mathrm{a}$ & $0.59 \pm 0.08 \mathrm{~b}$ & $0.89 \pm 0.10 \mathrm{ab}$ & $0.96 \pm 0.13 \mathrm{a}$ & $1.21 \pm 0.16 \mathrm{a}$ & $0.69 \pm 0.10 \mathrm{a}$ \\
\hline $\begin{array}{l}\text { Chlorophyll-b (mg/ } \\
\text { g of FW) }\end{array}$ & $0.22 \pm 0.03 \mathrm{a}$ & $0.20 \pm 0.04 \mathrm{~b}$ & $0.28 \pm 0.05 \mathrm{a}$ & $0.33 \pm 0.05 \mathrm{~b}$ & $0.38 \pm 0.08 \mathrm{a}$ & $0.22 \pm 0.04 \mathrm{~b}$ \\
\hline $\begin{array}{l}\text { Total chlorophyll- } \\
\mathbf{a}+\mathbf{b} \text { (mg/g of FW) }\end{array}$ & $0.86 \pm 0.10 \mathrm{~b}$ & $0.79 \pm 0.12 \mathrm{ab}$ & $1.17 \pm 0.15 \mathrm{a}$ & $1.29 \pm 0.19 \mathrm{ab}$ & $1.59 \pm 0.24 \mathrm{a}$ & $0.91 \pm 0.14 \mathrm{a}$ \\
\hline Ratio (a/b) & $2.01 \pm 0.15 \mathrm{~b}$ & $1.92 \pm 0.16 \mathrm{a}$ & $3.23 \pm 0.18 \mathrm{~b}$ & $2.22 \pm 0.09 \mathrm{~b}$ & $3.19 \pm 0.21 \mathrm{ab}$ & $2.77 \pm 0.07 \mathrm{a}$ \\
\hline $\begin{array}{l}\text { Carotenoids (mg/g } \\
\text { of FW) }\end{array}$ & $0.32 \pm 0.02 \mathrm{ab}$ & $0.16 \pm 0.02 \mathrm{a}$ & $0.31 \pm 0.02 \mathrm{ab}$ & $0.27 \pm 0.02 \mathrm{ab}$ & $0.37 \pm 0.03 \mathrm{~b}$ & $0.19 \pm 0.01 \mathrm{ab}$ \\
\hline
\end{tabular}

The photosynthetic pigment contents including the total chlorophyll $(\mathrm{Chl} a+b)$, carotenoids and $\mathrm{Chl} \mathrm{a} / \mathrm{b}$ ratio were significantly enhanced with the plant growing under the $\mathrm{R}_{30} \mathrm{~B}_{70}$ combination of LED light spectra compared other light treatments.

Mean values followed by a different letter within a row indicate significant differences $(P<0.05)$ according to Tukey's test. Values are mean \pm SE of 15 plants.

and $\mathrm{R}_{70} \mathrm{~B}_{30}$ combination of LED light $\left(138.55 \mathrm{mg} \mathrm{g}^{-1}\right.$ FW). However, a considerably reduced quantity of the carbohydrates was observed with the plants exposed to the monochromatic $B_{100}$ LED light, followed by $\mathrm{R}_{30} \mathrm{~B}_{70}$ combined LED light spectra (Fig. 3 A). Biochemical investigations of the soluble protein showed a significantly enhanced content with the plants exposed to in $\mathrm{B}_{100}$ LED light ( $\left.8.45 \mathrm{mg} \mathrm{g}^{-1} \mathrm{FW}\right)$, and combination of $\mathrm{R}_{30} \mathrm{~B}_{70}$ light $\left(7.42 \mathrm{mg} \mathrm{g}^{-1} \mathrm{FW}\right)$, however minimum quantity of proteins were observed with the plants exposed to the monochromatic in $\mathrm{R}_{100}$ Led light (Fig. 3 B). The quantification of the total phenolic content in the leaf samples of the plants exposed to $B_{100}$ and $R_{30} B_{70}$ LED light spectra showed enhanced quantity $\left(4.82 \mathrm{mg} \mathrm{g}^{-1}\right.$ FW and $4.55 \mathrm{mg} \mathrm{g}^{-1} \mathrm{FW}$ respectively) as compared to all other LED treatments as represented in Fig. 3 C. It is important to emphasize that the overall soluble carbohydrates and proteins contents were enhanced with the plants maintained under the $\mathrm{R}_{30} \mathrm{~B}_{70}$ combination of LED light.

\section{Estimation of reactive oxygen species (ROS) scavenging enzyme}

All the LED light spectrum significantly affected the ROS scavenging antioxidant enzymes which required for removal of the reactive free radicals produced in the cells. The plants exposed to $\mathrm{R}_{30} \mathrm{~B}_{70}$ LED light combination showed enhanced enzyme activity of superoxide-dismutase (SOD, 33.32 $\pm 0.22 \quad \mathrm{U} \mathrm{mg}^{-1}$ protein $\mathrm{min}^{-1}$ ), catalase peroxidase (CAT, 6.77 \pm 0.02 $\mu \mathrm{M} \quad \mathrm{H}_{2} \mathrm{O}_{2} \mathrm{mg}^{-1}$ protein $\mathrm{min}^{-1}$ ), and ascorbateperoxidase (APX, 33.34 $\pm 0.15 \mathrm{U} \mathrm{mg}^{-1}$ protein $\mathrm{min}^{-1}$ ) and total ascorbate content (AsA, $1.06 \pm 0.02 \mathrm{mg} \mathrm{g}^{-1}$ FW) in comparison to all other LED light (Fig. 4 A-D). However, the monochromatic $\mathrm{B}_{100}$ LED also caused an increase in the enzyme activity in comparison with other monochromatic and $\mathrm{W}_{100}$ LED light as shown in the Fig. 4.

\section{Tubers yield with the plants growing under various LED light spectra}

The potato plants growing under various LED light spectrum also impacted on the tuberization efficiency and total yield in potato. The potato plants exposed to the monochromatic $\mathrm{B}_{100}$ LED light showed bigger size $(>26 \mathrm{~mm})$ and lower number of tubers per plant $(4.67 \pm 1.20)$ with enhanced fresh and dry weight of tubers (Table 4). The plants growing under the monochromatic $R_{100}$ LED light yielded small sized $(<12 \mathrm{~mm})$ and slightly increased number tubers $(6.00 \pm 1.00)$ with decreased fresh and dry weight of tubers. However, the potato plants exposed to the $\mathrm{R}_{30} \mathrm{~B}_{70}$ combination of LED spectra showed larger tubers (16-21 mm), increased number of tubers per plant $(9.33 \pm 0.88)$ with enhanced fresh and dry weight
(A)

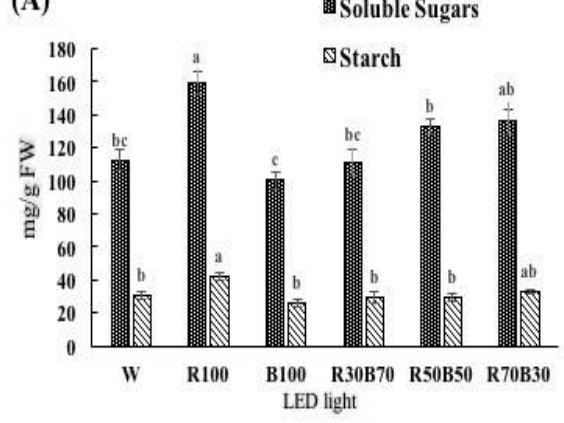

(B)

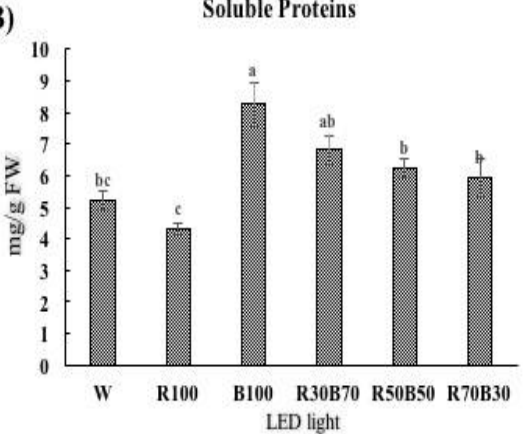

(C)

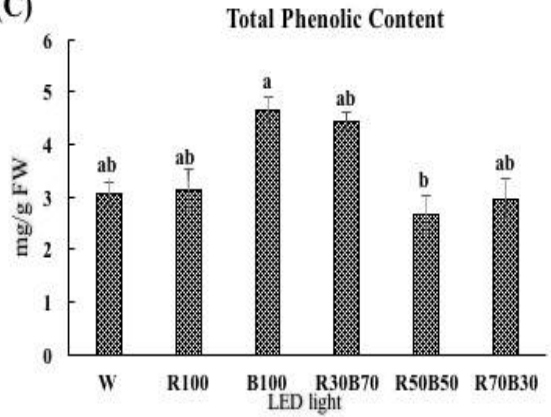

Fig. 3. Soluble carbohydrates, protein and phenolic content of the potato plants grown under the various LED light spectrum. Different letters in each bar graph indicate significant differences $(\mathrm{P}<0.05)$.

A. Soluble sugar and starch increased prominently with $\mathrm{R}_{100}$ and $\mathrm{R}_{70} \mathrm{~B}_{30}$ combined LED light by $40 \%$ and $35 \%$ in comparison to the $\mathrm{W}_{100}$.

B. Soluble proteins enhanced with $\mathrm{B}_{100}$ and $\mathrm{R}_{30} \mathrm{~B}_{70}$ combined LED light by $75 \%$ and $55 \%$ in comparison to the $\mathrm{W}_{100}$.

C. Total phenolic content also increased with $\mathrm{B}_{100}$ and $\mathrm{R}_{30} \mathrm{~B}_{70}$ combined LED light by $76 \%$ and $71 \%$ in comparison to the $\mathrm{W}_{100}$. 


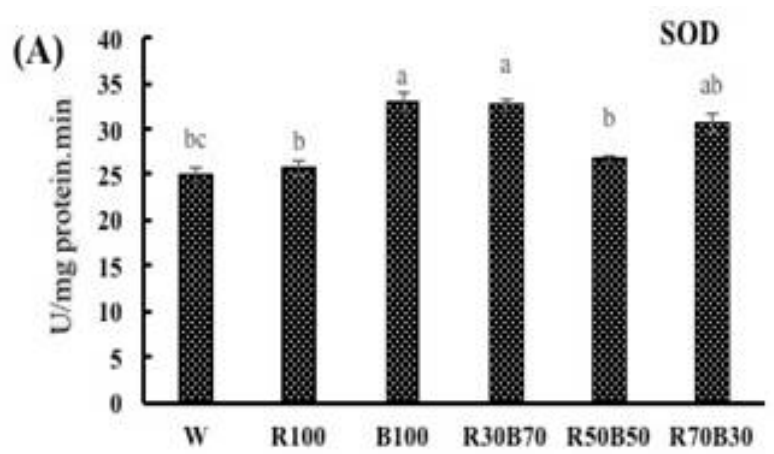

(C)

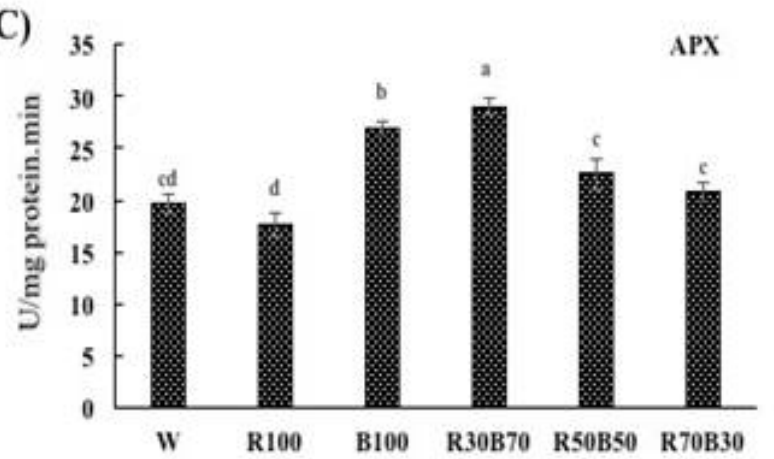

(B)
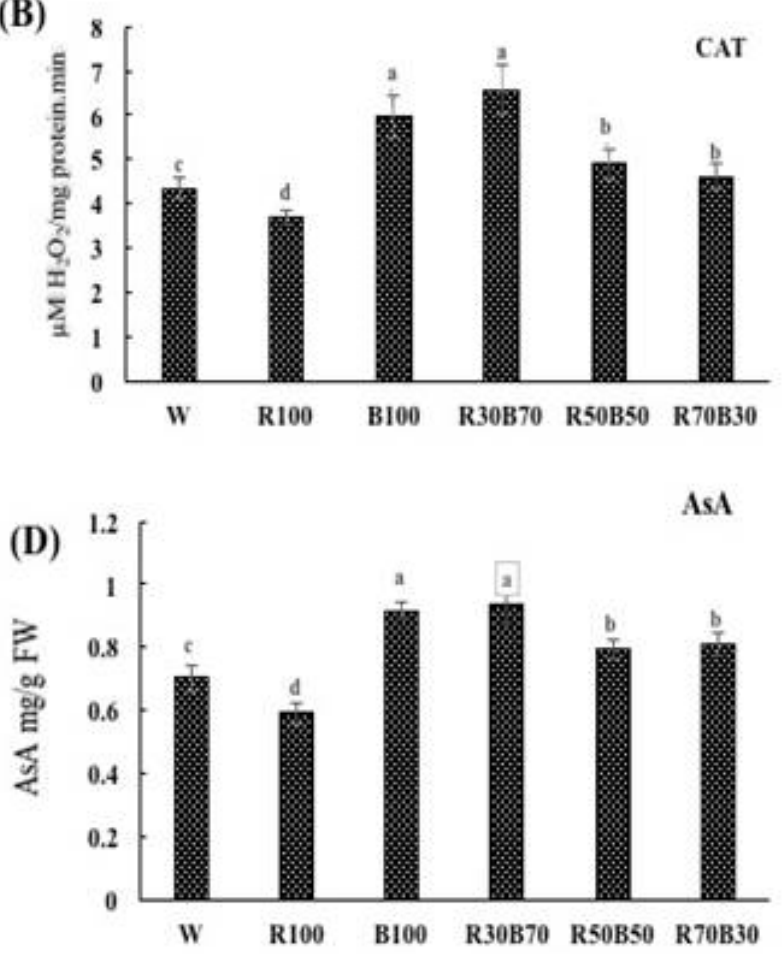

Fig. 4. Specific enzyme activity of ROS scavenging in potato plants grown under the various LED light spectrum.

SOD, CAT, APX, and ascorbate activities are represented from A-E. The values are presented as the mean \pm SEM of three replicates. ${ }^{*}$, Mean was significantly different at $\mathrm{P} \backslash 0.01$

as well as tuber yield per plants $(252.61 \pm 27.73 \mathrm{~g})$ in comparison with other combined or $\mathrm{W}_{100}$ LED light (Table 4).

\section{Discussion}

Improvement of growth parameters with combined RB spectra of LED light

This study was done to evaluate the changes in morphological and biochemical characteristics of potato plants maintained constantly under various LEDs light spectrum. It was observed that the plants grown under the monochromatic $\mathrm{R}_{100}$ LED light showed an thin and elongated stems, while stunted morphology with thicker stem and increased number of branches were observed with the plants grown under monochromatic $B_{100}$ LED spectra. Similar observations were recorded in Norway Spruce (Picea abies) seedlings where red light illumination prompted elongated stems and blue light subdued the phenomenon (43). Biochemical analysis revealed that the red light spectra induced the biosynthesis of endogenous gibberellin (GA) level in plant twice to that of the plant growing under the blue light spectra. Changes in the stem elongation growing under the $R_{100}$ LED or shortening of plant under the $B_{100}$ LED might be due to alteration in the cellular GA level via the red and blue light-mediated GA signaling pathway. However, the combined $\mathrm{R}_{30} \mathrm{~B}_{70}$ light spectra produced a balanced GA level in the plants and, therefore, the plant attained better growth parameters in terms of elongated stem length, diameter and enhanced branching. As reported earlier, the combined spectrum of RB LEDs was found to be more conducive for stem elongation than the normal white light $(23,44,45)$. Overall, the results of this study also exhibited that the combined spectrum of B and R LED (at 30:70 combination) had a synergistic effect on stem growth.

The potato plants exposed to $B_{100}$ LED spectrum exhibited an enhanced number of leaves with increased leaf area (Table 1). This might be due to increase in the plant hormone cytokinin growing

Table 4. Potato tuber yield grown under various LEDs light spectrum after 12 weeks period

\begin{tabular}{lrrrrrr}
\hline \multicolumn{1}{c}{ Light Treatment } & \multicolumn{1}{c}{ White } & \multicolumn{1}{c}{$\mathbf{R}_{\mathbf{1 0 0}}$} & \multicolumn{1}{c}{$\mathbf{B}_{100}$} & \multicolumn{1}{c}{$\mathbf{R}_{\mathbf{5 0}} \mathbf{B}_{\mathbf{5 0}}$} & $\mathbf{R}_{\mathbf{3 0}} \mathbf{B}_{70}$ & $\mathbf{R}_{70} \mathbf{B}_{\mathbf{3 0}}$ \\
\hline Tuber size (mm) & $18.26 \pm 1.54 \mathrm{a}$ & $15.59 \pm 0.91 \mathrm{a}$ & $33.75 \pm 1.91 \mathrm{ab}$ & $20.81 \pm 1.23 \mathrm{a}$ & $25.36 \pm 1.25 \mathrm{~b}$ & $21.32 \pm 0.58 \mathrm{a}$ \\
\hline Total Tuber No. per plant & $5.67 \pm 0.33 \mathrm{a}$ & $6.00 \pm 1.00 \mathrm{a}$ & $4.67 \pm 1.20 \mathrm{~b}$ & $6.33 \pm 0.88 \mathrm{a}$ & $9.33 \pm 0.88 \mathrm{~b}$ & $7.33 \pm 0.88 \mathrm{~b}$ \\
\hline Tuber F.W. (gm) & $20.72 \pm 2.07 \mathrm{~b}$ & $13.34 \pm 1.45 \mathrm{a}$ & $26.81 \pm 1.10 \mathrm{~b}$ & $23.88 \pm 2.12 \mathrm{a}$ & $28.97 \pm 4.23 \mathrm{ab}$ & $19.91 \pm 1.12 \mathrm{ab}$ \\
\hline Tuber D.W. (gm) & $7.00 \pm 1.06 \mathrm{~b}$ & $5.79 \pm 1.03 \mathrm{~b}$ & $10.94 \pm 1.09 \mathrm{ab}$ & $10.25 \pm 1.06 \mathrm{~b}$ & $13.67 \pm 1.03 \mathrm{~b}$ & $7.00 \pm 1.02 \mathrm{a}$ \\
\hline Tuber Yield per plant (gm) & $117.92 \pm 15.97 \mathrm{ab}$ & $77.75 \pm 9.77 \mathrm{ab}$ & $146.84 \pm 27.76 \mathrm{~b}$ & $134.40 \pm 11.94 \mathrm{a}$ & $252.61 \pm 27.73 \mathrm{a}$ & $146.22 \pm 19.34 \mathrm{a}$
\end{tabular}

The data in table clearly indicates that $\mathrm{R}_{30} \mathrm{~B}_{70}$ larger sized with increased tuber number and fresh and dry weight.

Mean values followed by a different letters within a row indicate significant differences $(P<0.05)$ according to Tukey's test. Values are mean \pm SE of 15 plants. 
under the blue light spectrum, which also has been reported to augment the overall plant growth via increasing the plant leaf area and number $(46,47)$. Similar observations were also recorded in Phaeodactylum tricornutum where the blue light spectra augmented in the leaf development (48). The combined spectra of $\mathrm{R}_{30} \mathrm{~B}_{70}$ showed enhanced number of leaves with better leaf area than the $W_{100}$ due to the synergistic effect and balanced hormone biosynthesis in the plants. Similar observations were also recorded in other plant species such as grape (23), strawberry (45), upland cotton (49) and tomato (50). Since the plant leaf has the capacity to absorb R and B-light with a greater extend, hence, the combined spectrum of RB LEDs might deliver essential energy for photosynthesis to synthesize enhanced content of soluble protein, sugar and starch $(51,52)$.

The guard cells found in stomata surround the stomatal pore that regulates the gaseous exchange. Stomata also serve as hydraulic valves on the aerial parts of plants. light intensity affects the development of stomata as well as stomatal conductivity. Results showed the presence of an elliptical stomata with the plants grown under eventually all the LED light except with the plants grown under the $W_{100}$ LED light a circular nonfunctional stomata observed (Fig. 2). This might be due to presence of fewer blue light spectra in the white LED light $\left(\mathrm{W}_{100}\right)$ leading to the development of spherical nonfunctioanl stomata while the blue lightinduced the functionally better stomata in the leaves. Similar observations of round nonfunctional stomata with the potato growing under the while LED has been reported earlier (53). Smaller stomata with the plant growing under the $\mathrm{R}_{100}$ is also due to lack of blue spectra which has been reported to received directly by phototropin thus activating a signal cascade for the development of elliptically functional stomata in leaves (54-56). The result also showed that enhanced percentage of blue spectra augmented the development of functional stomata, therefore, presence of balanced spectrum was crucial for functional stomata which was observed with the plant maintained under the $\mathrm{R}_{30} \mathrm{~B}_{70}$ combination of LED light. Similarly, the plant fresh and dry weight were also improved with the plant developed under the continuous presence of combined $\mathrm{R}_{30} \mathrm{~B}_{70}$ light signifying that the collective spectrum or broad spectrum added maximum to biomass buildup in potato plants. A comparable result was also observed in other in-vitro cultured plantlets including the potato $(13,17,57)$.

\section{Biochemical analysis of potato plants grown under various LED light spectra}

Biochemical assay of chlorophyll revealed an enriched total $\mathrm{Chl}(\mathrm{a}+\mathrm{b})$ content in the plants maintained under the $\mathrm{R}_{30} \mathrm{~B}_{70}$ combination and $\mathrm{W}_{100}$ LED light. Comparatively, a lower content of total Chl $(\mathrm{a}+\mathrm{b})$ were observed with the plants maintained under the $\mathrm{R}_{100}$ LED light spectra. In a similar experiment (58), the grapes plantlets were grown in presence of various spectra of LED light under invitro conditions and a significant inhibition in the chlorophyll (Chl) biosynthesis were observed with the plants exposed to the red LED light, while the blue light eradiation augmented the chlorophyll content in the leaves of the grapes. These results were also in consistent with our observations in the case of potato grown under various LED spectra. However, there are reports on increase in the total chlorophyll content with the plants grown under the monochromatic $R_{100}$ light and decrease in $B_{100}$ LED and vice versa also in different genotype of potato (59). Therefore, it seems that impact of the light spectrum on Chl biosynthesis is prominently species/ cultivar specific. A conclusion was drawn that a combined spectrum of $\mathrm{R}_{30} \mathrm{~B}_{70}$ LED light spectra facilitated Chl biosynthesis in potato leaves which also induced the plants to growth with enhanced health index.

The light mediated regulation of carbohydrate and protein metabolism in plants has already been established. The monochromatic red light reported to play an important role in the synthesis and accumulation of starch, while blue light enabled the plant for enhanced biosynthesis of soluble proteins in grapes (58). Therefore, the combination of $\mathrm{R}_{30} \mathrm{~B}_{70}$ light spectra was expected to induce the biosynthesis of both, the soluble carbohydrates and proteins as was observed in this study also which was in agreement of earlier report of induction of the cellular proteins and carbohydrates in alga, diatoms and in potato cultivar maintained under a light condition with the maximum percentage of blue light irradiation $(17,60$, 61).

Protection from the photo-oxidative damage in the plant is reported to be achieved via synthesis of various antioxidants, carotenoids, tocopherols, ascorbate, and phenolic compounds (62, 63). Therefore, quantification of phenolic compounds was also done to find-out the light-mediated change in the antioxidant capacity of potato plant growing under various LED spectra. The content of total phenolic compounds in leaves was significantly increased in the plants growing under $B_{100}$ and $R_{30} B_{70}$ combination of LED light as compared to that of $\mathrm{W}_{100}$ LED light (Fig $3 \mathrm{C}$ ). On the other hand, the content of total phenolic compounds in leaves showed a decreasing trends under other LED light conditions. This result is also in consistent with earlier studies in the red lettuce where an enhanced phenolic content were observed with the plants maintained under the higher irradiation of the Blue light $(64,65)$. In our result, the content of polyphenols shown to be greatly increased in the presence of combined $\mathrm{R}_{30} \mathrm{~B}_{70}$ (with enhanced percentage of Blue light) in vegetative tissues in plants supports earlier findings.

The antioxidant enzymes such as SOD, CAT, APX, and total ascorbate were also assayed through the spectrophotometric analysis with the potato maintained under various LED light conditions. The enzyme activities of the SOD, CAT and APX together with the cellular ascorbate pool was significantly enhanced in leaf tissues of potato grown under continuous B100 LED and combined $\mathrm{R}_{30} \mathrm{~B}_{70}$ LED spectra in comparison to the $\mathrm{W}_{100}$ or $\mathrm{R}_{100}$ LED light. Report on the activation of antioxidant enzymes in winter rye leaves grown under the blue LED light treatment than that the red or far-red light treatment 
has already been published (66). Similarly reports on increase in the activities of catalase (CAT), ascorbate peroxidase (APX) and other ROS scavenging enzymes in several plants grown under B and R LED light has been published in literature $(67,68)$. Moreover, an increase in the APX activity at the cellular level also indicated the increase in the total cellular ascorbate content (69). Taken together, the results also corroborated with earlier study that the potato grown under continuous presence LED light with increased Blue light percentage $\left(\mathrm{R}_{30} \mathrm{~B}_{70}\right.$ combination in present study) exhibited a positive effect on the activity of antioxidant enzymes in the potato which ultimately helped the plant to grow better and produced maximum tubers per plant in comparison with all other LED light irradiation.

\section{Enhanced tuber yield with plant under RB LED spectra}

It was estimated that the potato plants growing under the $\mathrm{B}_{100}$ LED spectra of light and combined spectrum of $\mathrm{R}_{30} \mathrm{~B}_{70}$ produced enhanced size, increased tuber numbers and enhanced fresh and dry weight, in comparison with other combined or monochromatic $\mathrm{R}_{100}$ and $\mathrm{W}_{100}$ LED light. Since the assimilates distribution is also an important factor for tuber size or weight (70), it is possible that more assimilates efficiently partitioned to underground tubers in plant growing under the combined LED $\mathrm{B}_{30} \mathrm{~B}_{70}$ spectra of light.

\section{Conclusion}

The current study showed that the combination of $\mathrm{R}$ and $B$ spectra of LED light irradiation at a ratio of 30:70 exhibited promotional effect on the growth and development via augmenting the synthesis of total chlorophyll, soluble proteins and carbohydrates as well as ROS removing antioxidant enzymes in potato. The potato plants maintained under the combined spectrum of $\mathrm{R}_{30} \mathrm{~B}_{70}$ also promoted tuber numbers per plant, larger size tuber with enhanced fresh weight and dry weight, in comparison with the plants grown under other LED light. In summary, the combined spectrum of red and blue $\left(\mathrm{R}_{30} \mathrm{~B}_{70}\right)$ LEDs was found suitable for plant development and recommended for the better growth and yield of early-maturing potato cultivated under the contained conditions.

\section{Acknowledgements}

RKP, NJ acknowledges the UGC research fellowship from Dr. Harisingh Gour Central University, Sagar, Madhya Pradesh, India. Authors also thank Dr Harisingh Gour Central University, Sagar, India for providing the Departmental Financial Support to conduct the experiments.

\section{Authors' contributions}

Conceptualization and designing of the research work by RKP and CPU; Execution of field/lab experiments and data collection by RKP and NJ;
Analysis of data and interpretation by AP and NJ; Preparation of manuscript by CPU and DSB.

\section{Conflict of interests}

The authors declare that they do not have any conflict of interest.

\section{References}

1. Hemavathi, Upadhyaya CP, Young KE, Nookaraju A, Kim HS Heung JJ, Oh OM, Aswath CR, Chun SC, Kim DH, Park SW. Overexpression of strawberry D-galacturonic acid reductase in potato leads to accumulation of vitamin $C$ with enhanced abiotic stress tolerance. Plant Sci. 2009;177:659-67. https://doi.org/ 10.1016/j.plantsci.2009.08.004

2. Hemavathi, Upadhyaya CP, Nookaraju A, Kim HS, Heung JJ, Oh $\mathrm{MH}$, Chun S, Kim DH, Park SW. Biochemical analysis of enhanced tolerance in transgenic potato plants over expressing D-galacturonic acid reductase gene in response to various abiotic stresses. Mol Breeding. 2011;28(1):105-15. https://doi.org/ 10.1007/s11032-010-9465-6

3. Halterman D, Guenthner J, Collinge S, Butler N, Douches D. Biotech potatoes in the 21st century: 20 years since the first biotech potato. American Journal of Potato Research. 2015;93:1-20. https://doi.org/10.1007/s12230-015-9485-1

4. Bagri DS, Upadhyaya DC, Kumar A, Upadhyaya CP. Over expression of PDX-II gene in potato (Solanum tuberosum L.) leads to the enhanced accumulation of vitamin B6 in tuber tissues and tolerance to abiotic stresses. Plant Science. 2018;272:26775. https://doi.org/10.1016/j.plantsci.2018.04.024

5. Kurilcik A, Miklusyte-Canova R, Dapkuniene S, Zilinskaite S, Kurilcik G, Tamulaitis G, Duchovskis P, Zukauskas A. In vitro culture of chrysanthemum plantlets using light-emitting diodes. Central European Journal of Biology. 2008;3(2):161-67. https://doi.org/10.2478/s11535-008-0006-9

6. Shin KS, Murthy HN, Heo JW, Hahn EJ, Paek KY. The effect of light quality on the growth and development of in vitro cultured Doritaenopsis plants. ActaPhysiol Plant. 2008;30:339-43. https://doi.org/10.1007/s11738-007-0128-0

7. Dale JE. The control of leaf expansion. Annual Review of Plant Physiology and Plant Molecular Biology. 1988;39(1):267-95.

8. Clouse SD. Integration of light and brassinosteroid signals in etiolated seedling growth. Trends in Plant Sci. 2001;6:443-45. https://doi.org/10.1016/S1360-1385(01)02102-1

9. Zhong JJ, Seki T, Kinoshita S, Yoshida T. Effect of light irradiation on anthocyanin production by suspended culture of Perilla frutescens. Biotech Bioeng.1991;38:653-58. https://doi.org/ 10.1002/bit.260380610

10. Chory J, Chatterjee M, Cook RK, Elich T, Fankhauser C, Li J, Nagpal P, Neff M, Pepper A, Poole D, Reed J, Vitart V. From seed germination to flowering light controls plant development via the pigment phytochrome. Proc Natl Acad Sci USA 1996;93:12066-12071. https://doi.org/10.1073/pnas.93.22.12066

11. Goins GD, Yorio NC, Sanwo MM, Brown CS. Photomorphogenesis, photosynthesis and seed yield of wheat plants grown under red light-emitting diodes (LEDs) with and without supplemental blue lighting. J Exp Bot. 1997;48:1407-13. https://doi.org/ 10.1093/jxb/48.7.1407

12. Tanaka M, Takamura T, Watanabe H, Endo M, Yanagi T, Okamoto K. In vitro growth of Cymbidium plantlets cultured under super bright red and blue light-emitting diodes (LEDs). J Hort Sci Biotechnol. 1998;73:39-44. https://doi.org/ 10.1080/14620316.1998.11510941

13. Gupta SD, Jatothu B. Fundamentals and applications of lightemitting diodes (LEDs) in in vitro plant growth and morphogenesis. Plant Biotechnology Reports. 2013;7:211-20. https:// doi.org/10.1007/s11816-013-0277-0

14. Saebø A, Krekling T, Appelgren M. Light quality affects photosynthesis and leaf anatomy of birch plantlets in vitro. Plant 
Cell Tissue Organ Cult. 1995;41:177-85. https://doi.org/10.1007/ BF00051588

15. Aksenova NP, Konstantinova TN, Sergeeva LI, Machachkova I, Golyanovskaya SA. Morphogenesis of potato plants in vitro. I. Effect of light quality and hormones. Journal of Plant Growth Regulation. 1994;13(3):143-46. https://doi.org/10.1007/ BF00196378

16. Miyashita Y, Kitaya Y, Kozai T. Effects of red and farred light on the growth and morphology of potato plantlets in vitro using light emitting diode as a light source for micro propagation. Acta Horticulturae. 1995;393:189-94. https://doi.org/ 10.17660/ActaHortic.1995.393.22

17. Chen LL, Xue XZ, Yang YD, Chen F, Zhao j, Wang XX, Khan AT, $\mathrm{Hu}$ YG. Effects of red and blue LEDs on in vitro growth and microtuberization of potato single-node cuttings. Frontiers of Agricultural Science and Engineering. 2018;5:197-205. https:// doi.org/10.15302/J-FASE-2018224

18. Vinterhalter D, Vinterhalter B, Orbović V. Photo- and gravitropic bending of potato plantlets obtained in vitro from singlenode explants. Journal of Plant Growth Regulation. 2012;31:560-69. https://doi.org/10.1007/s00344-012-9266-8

19. Pashkovskiy PP, Kartashov AV, Zlobin IE, Pogosyan SI, Kuznetsov VV. Blue light alters miR167 expression and microRNA-targeted auxin response factor genes in Arabidopsis thaliana plants. Plant Physiology and Biochemistry. 2016;104:146-54. https://doi.org/10.1016/j.plaphy.2016.03.018

20. Koehl K, Tohge T, Schoettler MA. Performance of Arabidopsis thaliana under different light qualities: comparison of lightemitting diodes to fluorescent lamp. Functional Plant Biology. 2017;44:727-38. https://doi.org/10.1071/FP17051

21. Kim SJ, Hahn EJ, Heo JW, Paek KY. Effects of LEDs on net photosynthetic rate, growth and leaf stomata of chrysanthemum plantlets in vitro. Sci Hortic (Amsterdam). 2004;101:143-51. https://doi.org/10.1016/j.scienta.2003.10.003

22. Lian ML, Hosakatte NM, Paek KY. Effects of light emitting diodes (LEDs) on the in vitro induction and growth of bulblets of lilium oriental hybrid 'Pesaro'. Sci Hortic. (Amsterdam). 2002;94:365-70. https://doi.org/10.1016/S0304-4238(01)00385-5

23. Nhut DT, Takamura T, Watanabe H, Okamoto K, Tanaka M. Responses of strawberry plantlets cultured in vitro under super bright red and blue light-emitting diodes (LEDs). Plant Cell Tissue Organ Cult. 2003;73:43-52. https://doi.org/10.1023/ A:1022638508007

24. Jao RC, Fang W. Growth of potato plantlets in vitro is different when provided concurrent versus alternating blue and red light photoperiods. Hort Science. 2004;39:380-82. https:/ doi.org/10.21273/HORTSCI.39.2.380

25. Yanagi T, Okamoto K, Takita S. Effects of blue, red and blue/red lights of two different PPF levels on growth and morphogenesis of lettuce plants. ActaHortic. 1996;440:117-22. https:// doi.org/10.17660/ActaHortic.1996.440.21

26. Okamoto K, Yanagi T, Kondo S. Growth and morphogenesis of lettuce seedlings raised under different combinations of red and blue light. Acta Hortic. 1997;435:149-58. https://doi.org/ 10.17660/ActaHortic.1997.435.14

27. Nhut DT, Hong LTA, Watanable H, Goi M, Tanaka M. Growth of banana plantlets cultured in vitro under red and blue lightemitting diodes (LED) irradiation source. Acta Horticulturae, The Hague. 2002;575c:117-24. https://doi.org/10.17660/ActaHortic. 2002.575 .10

28. Heo J, Lee C, Chakrabarty D, Paek K. Growth responses of marigold and salvia bedding plants as affected by monochromic or mixture radiation provided by a light-emitting diode (LED). Plant Growth Regulation. 2002;38(3):225-30. https://doi.org/10.1023/A:1021523832488

29. Tripathy BC, Brown CS. Root-shoot interaction in the greening of wheat seedlings grown under red light. Plant Physiol. 1995;107:407-11. https://doi.org/10.1104/pp.107.2.407

30. Zeng B, Wang QY, Tang C M. Anatomic analysis on heterosis in three transgenic bt pest-resistant hybrid cotton ( $G$. hirsutum L.). Acta Agronomica Sinica. 2008;34:496-505. https://doi.org/ 10.3724/SP.J.1006.2008.00496
31. Arnon DI. Copper enzymes in isolated chloroplasts. Polyphenoloxidase in Beta vulgaris. Plant Physiol. 1949;24:1-5. https:// doi.org/10.1104/pp.24.1.1

32. Porra RJ, Thompson WA, Kreidemann PE. Determination of accurate extinction coefficients and simultaneous equations for assaying chlorophylls $a$ and $b$ extracted with four differ ent solvents: verification of the concentration of chlorophyll standards by atomic absorption spectrometry. Biochim Biophys Acta. 1989;975:384-94. https://doi.org/10.1016/S00052728(89)80347-0

33. Welborn AR, Lichanthaler H. Formulae and program to determine total cartenoids and Chi a and b of leaf extracts in different solvents. In Advances in Photosynthesis Research (Sybesma, C. ed). Martinus Nijoff/Dr. W.Junk Publishers, The Hague/Boston/ Lancaster; 1984. p. 9-12. https://doi.org/ 10.1007/978-94-017-6368-4_3

34. Ciha AJ, Brun WA. Effect of pod removal on nonstructural carbohydrate concentration in soybean tissue 1. Crop Science. 1978;18(5):773-76. sci1978.0011183X001800050020x

35. Dubois M, Ciller KA, Rebers PA, Smith F. Colorimetric method for determination of sugars and related substances. Anal chem. 1956;28:350-56. https://doi.org/10.1021/ac60111a017

36. Sadasivam S, Manickam A. Biochemical methods for agricultural sciences. Wiley Eastern Limited, Madras; 1992. p. 1-246.

37. Bradford MM. A rapid and sensitive method for the quantitation of microgram quantities of protein utilizing the principle of protein-dye binding. Anal Biochem. 1976;72:248-54. https:// doi.org/10.1016/0003-2697(76)90527-3

38. Parida AK, Das AB, Das P. NaCl stress causes changes in photosynthetic pigments, proteins and other metabolic components in the leaves of a true mangrove, Bruguiera parviflora in hydroponic cultures. J Plant Biol. 2002;45:28-36. https://doi.org/ 10.1007/BF03030429

39. Kumar A, Dutt S, Bagler G, Ahuja PS, Kumar S. Engineering a thermo-stable superoxide dismutase functional at subzero to $>50^{\circ} \mathrm{C}$, which also tolerates autoclaving. Sci Rep. 2012;2:387. https://doi.org/10.1038/srep00387

40. Aebi HE. Catalase In: Methods of enzymatic analysis, Bergmeyer H U, editor. Verlag Chemie Weinhem; 1983. p. 27386.

41. Chance B, Maehly AC. Assay of catalases and peroxidases. Methods Enzymol. 1955;2:764-817. https://doi.org/10.1016/ S0076-6879(55)02300-8

42. Kampfenkel K, Van Montagu M, Inze D. Effect of iron excess on Nicotiana plumbaginifolia plants. Implications to oxidative stress. Plant Physiol. 1995;107:725-35. https://doi.org/10.1104/ pp.107.3.725

43. Ouyang FQ, Mao JF, Wang JH, Zhang SG, Li Y. Transcriptome analysis reveals that red and blue light regulate growth and phytohormone metabolism in Norway Spruce [Picea abies (L.) Karst]. PLoS ONE. 2015;10:1-19. https://doi.org/10.1371/journal.pone.0127896

44. Duong TN, Hong LA, Watanabe H, Goi M, Tanaka M. Efficiency of a novel culture system by using light-emitting diode (LED) on in vitro and subsequent growth of micropropagated banana plantlets. Acta Hortic. 2003;616:121-27. https://doi.org/ 10.17660/ActaHortic.2003.616.10

45. Puspa RP, Ikuo K, Ryosuke M. Effect of red-and blue-light-emitting diodes on growth and morphogenesis of grapes. Plant Cell Tiss Organ Cult. 2008;92:147-53. https://doi.org/10.1007/s11240 007-9317-1

46. Sergeeva LI, Machackova I, Konstantinova TN, Golyanovskaya SA, Eder J, Zaltsman OO, Hanus J, Aksenova NP. Morphogenesis of potato plants in vitro. II. endogenous levels, distribution and metabolism of IAA and cytokinins. Journal of Plant Growth Regulation. 1994;13:147-52. https://doi.org/10.1007/ BF00196379

47. Chen LL, Zhang K, Gong XC, Wang XQ, Zeng ZH, Hu YG. Effect of different LEDs light spectrum on the growth, leaf anatomy and chloroplast ultrastructure of potato plants in vitro and minituber production after transplanting in the greenhouse. J Integr Agric. 2019;18:2-13. https://doi.org/10.1016/S2095 3119(19)62633-X 
48. Schellenberger CB, Jungandreas A, Jakob T, Weisheit W, Mittag $\mathrm{M}$, Wilhelm $\mathrm{C}$. Blue light is essential for high light acclimation and photoprotection in the diatom Phaeodactylum tricornutum. Journal of Experimental Botany. 2013;64:483-93. https:// doi.org/10.1093/jxb/ers340

49. Li HM, Xu ZG, Tang CM. Effect of light-emitting diodes on growth and morphogenesis of upland cotton (Gossypium hirsutum L.) plantlets in vitro. Plant Cell Tissue Organ Cult. 2010;103:155-63. https://doi.org/10.1007/s11240-010-9763-z

50. Fan XX, Xu ZG, Liu XY, Tang CM, Wang LW, Han X. Effects of light intensity on the growth and leaf development of young tomato plants grown under a combination of red and blue light. Sci Hortic. 2013;153:50-55. https://doi.org/10.1016/j.scienta.2013.01.017

51. Klein RM. Effects of green light on biological systems. Biol Rev. 1992;67:199-284. 185X.1992.tb01019.x https://doi.org/10.1111/j.1469-

52. Smith H. Sensing the light environment: the functions of the phytochrome family. In: Kroneberg, Kendrick R E, editors. Photomorphogenesis in Plants. Kluwer Academic Publishers, UK. 1993; pp.377-416. https://doi.org/10.1007/978-94-011-1884-2_15

53. Mohamed $\mathrm{MH}$, Alsadon AA. Influence of ventilation and sucrose on growth and leaf anatomy of micropropagated potato plantlets. Scientia Horticulturae. 2010;123(3):295-300. https:// doi.org/10.1016/j.scienta.2009.09.014

54. Outlaw Jr, William H. Jr. Integration of cellular and physiological functions of guard cells. Critical Reviews in Plant Sciences. 2003;22(6):503-29. https://doi.org/10.1080/713608316

55. Shimazaki KI, Doi M, Assmann SM, Kinoshita T. Light regulation of stomatal movement. Annual Review of Plant Biology. 2007;58(1):219-47. annurev.arplant.57.032905.105434

56. Muneer S, Kim EJ, Park JS, Lee JH. Influence of green, red and blue light emitting diodes on multiprotein complex proteins and photosynthetic activity under different light intensities in lettuce leaves (Lactuca sativa L.). International Journal of Molecular Sciences. 2014;15(3):4657-70. https://doi.org/10.3390/ ijms15034657

57. Ma XF, Wang YP, Liu MX, Xu JM, Xu ZG. Effects of green and red lights on the growth and morphogenesis of potato (Solanum tuberosum L.) plantlets in vitro. Scientia Horticulturae. 2015;190:104-09. j.scienta.2015.01.006 https://doi.org/10.1016/

58. Li CX, Xu ZG, Dong RQ, Chang SX, Wang LZ, Khalil URM, Tao JM. An RNA-Seq analysis of grape plantlets grown in vitro reveals different responses to blue, green, red LED light and white fluorescent light. Frontiers in Plant Science. 2017;8:1-16. https://doi.org/10.3389/fpls.2017.00078

59. Su NN, Wu Q, Shen ZG, Xia K, Cui J. Effects of light quality on the chloroplastic ultrastructure and photosynthetic characteristics of cucumber seedlings. Plant Growth Regulation. 2014;73:227-35. https://doi.org/10.1007/s10725-013-9883-7

60. Korbee N, Figueroa FL, Aguilera J. Effect of light quality on the accumulation of photosynthetic pigments, proteins and my- cosporine-like amino acids in the red alga Porphyra leucosticte (Bangiales, Rhodophyta). Journal of Photochemistry and Photobiology Biology. 2005;80:71-78. https://doi.org/10.1016/j.jphotobiol.2005.03.002

61. Jungandreas A, Costa BS, Jakob T, Bergen MV, Baumann S, Wilhelm C. The acclimation of Phaeodactylum tricornutumto blue and red light does not influence the photosynthetic light reac tion but strongly disturbs the carbon allocation pattern. PLoS ONE. 2014;9:1-14. https://doi.org/10.1371/journal.pone.0099727

62. Samuoliene G, Brazaityte A, Urbonaviciute A, Sabajeviene G Duchovskis $P$. The effect of red and blue light component on the growth and development of frigo strawberries. Zemdirbyste. 2010;97:99-104. UDK 634.75:581.144.3.035]:631.559

63. Ashry NA, Mohamed HI. Impact of secondary metabolites and related enzymes in flax resistance and or susceptibility to powdery mildew. Afr J Biotechnol. 2011;7:78-85. https://doi.org/ 10.5897/AJB11.1023

64. Luthria DL, Mukhopadhyay S, Krizek DT. Content of total phenolics and phenolic acids in tomato (Lycopersicon esculentum Mill.) fruits as influenced by cultivar and solar UV radiation. Food Compos Analysis. 2006;19:771-77. https://doi.org/10.1016/ j.jfca.2006.04.005

65. Johkan M, Shoji K, Goto F, Hashida S, Yoshihara T. Blue lightemitting diode light irradiation of seedlings improves seedling quality and growth after transplanting in red leaf lettuce. Hort Sci. 2010;45:1809-14. https://doi.org/10.21273/ HORTSCI.45.12.1809

66. Schmidt M, Grief J, Feierabend J. Mode of translational activation of the catalase (cat1) mRNA of rye leaves (Secale cereale L.) and its control through blue light and reactive oxygen. Planta. 2006;223:835-46. https://doi.org/10.1007/s00425-005-0125-8

67. Xu Y, Sun X, Jin J, Zhou H. Protective effect of nitric oxide on light- induced oxidative damage in leaves of tall fescue. J Plant Physiol. 2010;167:512-18. https://doi.org/10.1016/ j.jplph.2009.10.010

68. Kim K, Kook HS, Jang YJ, Lee WH, Kamala-Kannan S, Chae JC Lee KJ. The effect of blue-light-emitting diodes on antioxidant properties and resistance to Botrytis cinerea in tomato. J Plant Pathol Microbiol. 2013;4(203):10-4172. https://doi.org/ $10.4172 / 2157-7471.1000203$

69. Upadhyaya CP, Venkatesh J, Gururani MA, Asnin L, Sharma K Ajappala H, Park SW. Transgenic potato overproducing Lascorbic acid resisted an increase in methylglyoxal under salinity stress via maintaining higher reduced glutathione level and glyoxalase enzyme activity. Biotechnol Letters. 2011;33(11):2297. https://doi.org/10.1007/s10529-011-0684-7

70. Asghari ZR, Maleki ZB, Sedghi E. Effect of in vitro chitosan application on growth and minituber yield of Solanum tuberosum L. Plant Soil and Environment. 2009;55:252-56. https://doi.org/ 10.17221/1018-PSE

71. Tukey JW. Exploratory data analysis. Addison-Wesley, Reading, UK; 1977. 